\title{
Analisis Faktor yang Berhubungan dengan Kejadian Karies Gigi Anak Usia Dini
}

\author{
Nur Afrinis ${ }^{\circledR}{ }^{\bowtie}$ Indrawati ${ }^{2}$, Nur Farizah ${ }^{3}$ \\ Gizi, Universitas Pahlawan Tuanku Tambusai (1) \\ Keperawatan, Universitas Pahlawan Tuanku Tambusai $(2,3)$ \\ DOI: $10.31004 /$ obsesi.v5i1.668
}

\begin{abstract}
Abstrak
Karies gigi merupakan gangguan kesehatan gigi yang paling sering terjadi pada anak usia dini. Karies gigi menyebabkan gigi menjadi keropos, berlubang, patah, sehingga mengakibatkan pertumbuhan kurang maksimal. Penelitian bertujuan menganalis hubungan faktor pengetahuan ibu, kebiasaan menggosok gigi dan kebiasaan konsumsi makanan manis dengan kejadian karies gigi anak usia dini. Penelitian ini merupakan observasional analitik dengan desain cross sectional. Populasi penelitian semua siswa dan orang tua siswa di TK Melati Dharma yang berjumlah 98 siswa dan 98 orang tua dengan menggunakan teknik total sampling. Alat pengumpulan data berupa kuesioner dan observasi. Analisa data univariat dan bivariat dengan uji chi-square. Hasil penelitian didapatkan sebagian besar pengetahuan ibu kurang tentang kebersihan gigi dan mulut, kebiasaan anak menggosok gigi tidak baik, anak terbiasa mengkonsumsi makanan manis dan sebagian besar anak menderita karies gigi. Berdasarkan uji chi-square terdapat hubungan signifikan antara pengetahuan ibu tentang kesehatan gigi dan mulut, kebiasaan menggosok gigi dan kebiasaan konsumsi makanan manis dengan kejadian karies gigi.
\end{abstract}

Kata Kunci : pengetahuan ibu; konsumsi makanan manis; kebiasaan menggosok gigi; karies gigi

\begin{abstract}
Abstact
Dental caries is a dental health disorder that most often occurs in early childhood, causing teeth to become porous, hollow, even broken, resulting in less than maximum growth. This study aims to analyze the relationship between maternal knowledge, tooth brushing habits and sweet food consumption habits with the incidence of early childhood dental caries. This study was analytic observational research with cross sectional design. The population in this study were all children and parents of students in TK Melati Dharma Wanita with a sample of 98 students and 98 parents using a total sampling technique. Data collection tools used were questionnaires and observation. Data analysis used were univariate and bivariate analysis with chi-square test. The results showed that maternal knowledge about oral health was in the poor category, the habit of children brushing their teeth was not good, children are used to consuming sweet foods, and most children suffered from dental caries. Based on the chi-square test there was a relationship between maternal knowledge about dental and mouth health with the incidence of dental caries, there was a relationship between the habit of brushing teeth and the incidence of dental caries and there was a relationship between sweet food with dental caries.
\end{abstract}

Keywords: mother's knowledge; tooth brushing habits; consumption of sweet foods; dental carries

Copyright (c) 2020 Nur Afrinis, Indrawati, Nur Farizah

$\square$ Corresponding author:

Email Address : afrinis.eva@gmail.com (Bangkinang, Indonesia)

Received 17 July 2020, Accepted 4 August 2020, Published 15 August 2020 


\section{PENDAHULUAN}

Kesehatan gigi dan mulut memiliki peranan yang sangat penting, terutama dalam proses pencernaan makanan. Perawatan gigi harus dimulai sedini mungkin karena akan berpengaruh terhadap kesehatan (Alshehri \& Nasim, 2015). Masalah utama kesehatan gigi dan mulut anak adalah karies gigi. Karies gigi merupakan penyakit jaringan gigi yang ditandai dengan kerusakan jaringan, mulai dari permukaan gigi yaitu dari email, dentin, dan meluas ke arah pulpa. Karies gigi merupakan salah satu bentuk kerusakan gigi yang paling sering dialami anak usia prasekolah, yang dapat mengganggu proses tumbuh kembangnya.

Masalah karies gigi pada anak usia pra sekolah cukup berbahaya yaitu gigi menjadi keropos, berlubang, bahkan patah sehingga membuat anak mengalami kehilangan daya kunyah dan mengganggu pencernaan (Widayati, 2014). Selain itu karies gigi juga dapat menyebabkan rasa sakit pada gigi sehingga berkurangnya frekuensi kehadiran anak ke sekolah, mengganggu konsentrasi belajar, mempengaruhi nafsu makan dan asupan makanan sehingga dapat memengaruhi status gizi dan pada akhirnya mengakibatkan gangguan pertumbuhan fisik anak (Fatimatuzzahro et al., 2016). Hal ini akan berpengaruh terhadap status gizi dan kesehatan anak.

Orang tua memiliki peranan penting dalam memelihara kesehatan gigi anak usia dini. Hasil studi mengatakan bahwa faktor-faktor psikososial orang tua telah terbukti berdampak negatif terhadap kesehatan mulut anak (Putri Abadi \& Suparno, 2019). Pengetahuan ibu yang merupakan orang terdekat dengan anak dalam pemeliharaan kesehatan memberikan pengaruh yang signifikan terhadap sikap dan perilaku anak. Anak pra sekolah umumnya tidak tahu dan belum mampu untuk menjaga kesehatan rongga mulut mereka, sehingga orang tua bertanggung jawab untuk mendidik mereka dengan benar (Rompis et al., 2016).

Orang tua dengan pengetahuan kurang mengenai kesehatan gigi dan mulut merupakan penyebab dari terbentuknya karies gigi, karena mereka beranggapan bahwa karies gigi merupakan suatu hal yang wajar dialami pada anak kecil dan hal ini tidak perlu untuk terlalu dikhawatirkan dan cenderung dianggap remeh karena jarang membahayakan jiwa kebiasaan menggosok gigi akan menghindari terbentuknya lubang-lubang gigi, penyakit gigi dan gusi. Jika orang tua/keluarga memiliki perilaku yang baik dalam menjaga kesehatan mulut maka anak akan memiliki perilaku yang baik juga (Susi et al., 2012).

Hasil Riset Kesehatan Dasar atau Riskesdas 2018 menyebutkan bahwa 93 persen anak usia dini, yakni dalam rentang usia 5-6 tahun, mengalami gigi berlubang (Penelitian dan Pengembangan Kesehatan Kementerian Kesehatan RI, 2018). Anak prasekolah mengalami proses pembentukan karies karena kurangnya perhatian orang tua terhadap makanan sehari-hari dan menyikat gigi. Pada umur 3- 5 tahun, anak tersebut mulai melakukan sesuatu berdasarkan keinginanya salah satunya mulai mencoba berbagai rasa makanan dalam bentuk apapun sehingga dapat memberikan dampak buruk bagi gigi apabila anak tersebut tidak memerhatikan solusi pencegahan timbulnya karies.

Anak-anak memasuki usia sekolah mempunyai resiko karies yang tinggi, karena pada usia sekolah ini anak-anak biasanya suka jajan makanan dan minuman sesuai keinginannya (Worotitjan et al., 2013). Konsumsi makanan manis seperti karbohidrat seperti sukrosa yang dapat menyebabkan terjadinya karies gigi dikenal dengan sebutan makanan kariogenik. Pada umumnya anak usia dini sangat suka makan makanan manis tetapi kesadaran untuk menjaga dan memelihara kebersihan mulutnya sangat kurang (Utami, 2018).

Berdasarkan studi pendahuluan yang telah dilakukan peneliti di TK Melati Dharma Wanita Air Tiris Kecamatan Kampar Kabupaten Kampar Riau diperoleh sebagian besar siswa-siswi mengalami karies gigi . Dalam penelitian ini, disajikan data faktual mengetahui hubungan pengetahuan ibu tentang kesehatan gigi dan mulut, kebiasaan menggosok gigi dan konsumsi makanan manis dengan kejadian karies gigi sebagai landasan atau acuan dalam menentukan solusi penanggulangan karies gigi pada anak usia dini. Adapun tujuan 
DOI: 10.31004/obsesi.v5i1.668

penelitian ini untuk mengetahui hubungan pengetahuan ibu tentang kesehatan gigi dan mulut, kebiasaan menggosok gigi dan konsumsi makanan manis dengan kejadian karies gigi di TK Melati Dharma Wanita Kabupaten Kampar Riau.

\section{METODOLOGI}

Penelitian ini merupakan penelitian observasional analitik dengan desain cross sectional. Penelitian ini dilaksanakan di TK Melati Dharma Wanita Air Tiris Kecamatan Kampar Kabupaten Kampar Riau tanggal 02 Juni - 30 Juni Tahun 2019. Populasi dalam penelitian ini adalah semua anak dan orang tua siswa di TK Melati Dharma Wanita yang berjumlah 98 orang tua dan 98 anak usia dini. Teknik pengambilan sampel menggunakan teknik total sampling. Adapun rancangan penelitian dalam penelitian ini adalah:

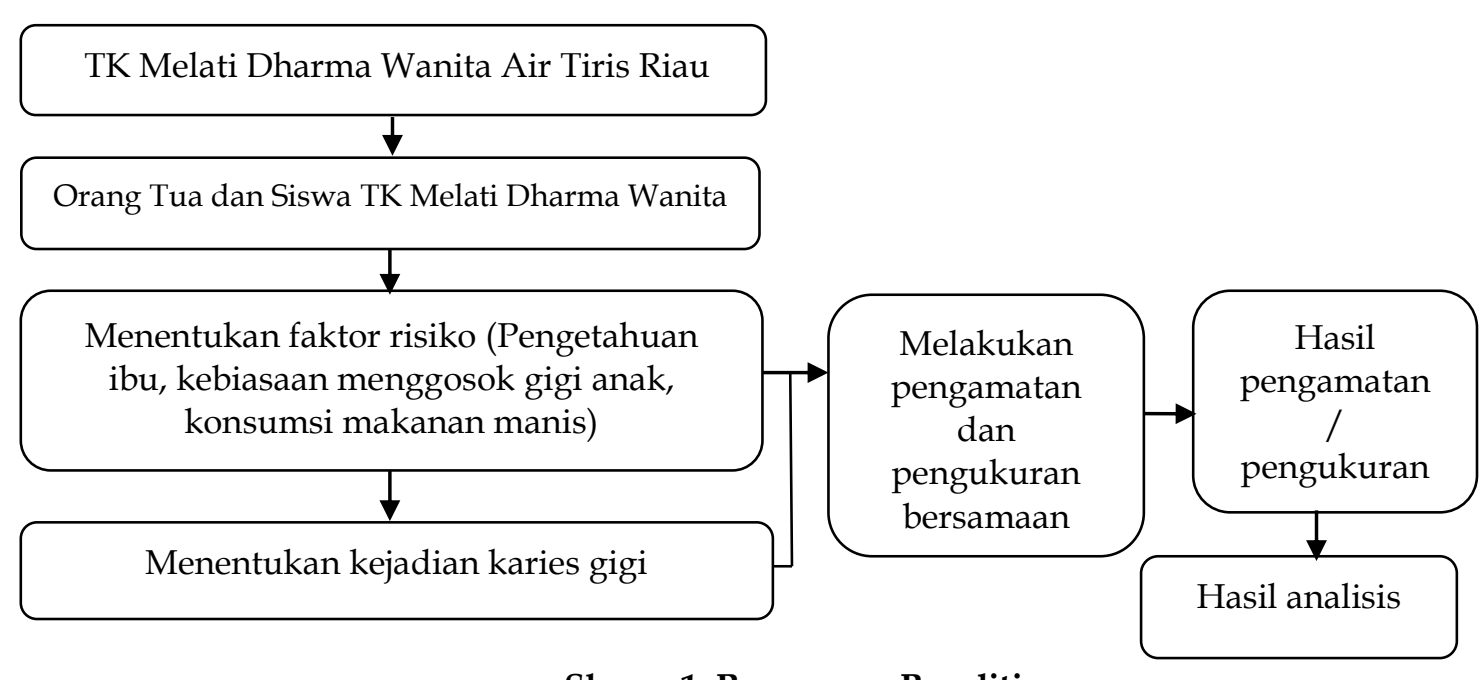

\section{Skema 1. Rancangan Penelitian}

Alat pengumpulan data yang digunakan pada penelitian yaitu berupa kuesioner dan observasi. Kuesioner yang berkaitan dengan pengetahuan ibu tentang kesehatan gigi dan mulut berjumlah 20 pertanyaan, 5 pertanyaan kebiasaan menggosok gigi, 10 pertanyaan tentang konsumsi makanan manis. Untuk kejadian karies gigi menggunakan observasi. Analisa Data menggunakan Analisa Univariat dan bivariate dengan uji Chi-Square ( $\left.\mathrm{X}^{2}\right)$

\section{HASIL DAN PEMBAHASAN}

Berdasarkan hasil pengolahan kuisioner dan observasi diperoleh pengetahuan ibu tentang kesehatan gigi dan mulut kurang (53.1\%), Kebiasaan anak menggosok gigi tidak baik $(60.2 \%)$, anak terbiasa mengkonsumsi makanan manis $(63.3 \%)$ dan sebagian besar anak mengalami karies gigi $(58.2 \%)$. Hasil analisa univariat dan bivariate dapat dilihat dari grafik dan tabel dibawah ini.

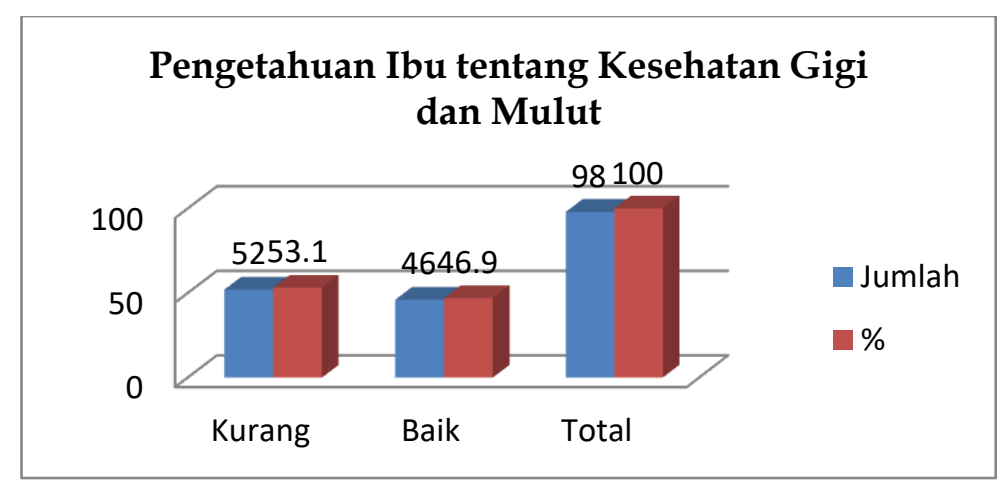

Grafik 1. Pengetahuan Ibu tentang Kesehatan Gigi dan Mulut 
DOI: 10.31004/obsesi.v5i1.668

Berdasarkan hasil pengolahan kuisioner yang ditampilkan pada grafik 1 sebagian besar pengetahuan ibu tentang kesehatan gigi dan mulut berada pada kategori kurang $(53,1 \%)$. Pengetahuan merupakan domain yang sangat penting untuk terbentuknya tindakan seseorang (Lintang et al., 2015). Pengetahuan ibu tentang kesehatan gigi dan mulut sangat penting dalam mendasari terbentuknya prilaku yang mendukung kebersihan gigi dan mulut anak usia dini. Penelitian ini sejalan dengan penelitian yang dilakukan oleh Sukarsih (2018) yang menyatakan bahwa sebagian besar pengetahuan ibu tentang pemeliharaan kesehatan gigi dan mulut kategori rendah sebanyak yaitu 53 orang $(58,9 \%)$. Berdasarkan penelitian dan wawancara dengan ibu, rendahnya pengetahuan ibu tentang kesehatan gigi dan mulut kriteria disebabkan karena rendahnya pendidikan ibu dan kurangnya kegiatan promotif atau penyuluhan oleh tenaga kesehatan mengenai kesehatan gigi anak pra sekolah.

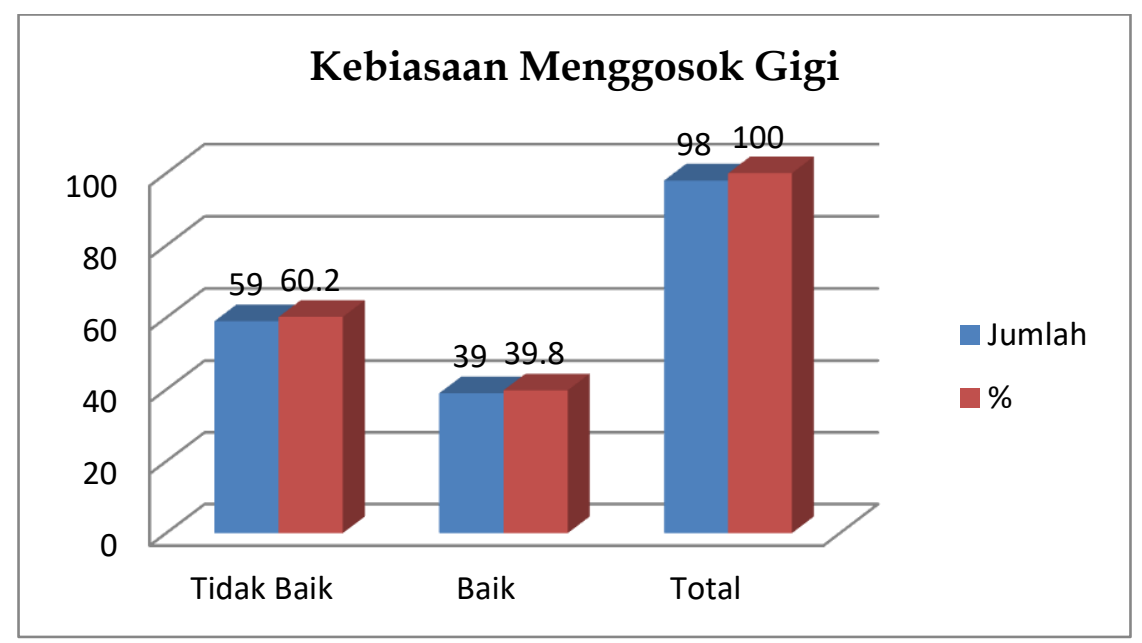

Grafik 2. Kebiasaan menggosok gigi anak

Berdasarkan grafik 2 dapat dilihat bahwa dari 98 responden sebanyak 59 (60,2\%) anak memiliki kebiasaan tidak baik dalam menggosok gigi. Penelitian ini tidak sejalan dengan penelitian yang dilakukan Sari, Tahun 2014 yang menyatakan bahwa sebagian besar anak memiliki kebiasaan yang baik (53.1\%) dalam menggosok gigi. Menggosok gigi adalah membersihkan gigi dari sisa-sisa makanan, bakteri, dan plak. Dalam membersihkan gigi, harus memperhatikan pelaksanaan waktu yang tepat, penggunaan alat yang tepat, dan cara yang tepat untuk membersihkan gigi. Pencegahan karies gigi pada anak memerlukan peran serta orang tua, karena orang tua adalah yang paling sering berinteraksi dengan anak sehingga berpengaruh pada pemeliharaan kesehatan dan kebersihan gigi anak, salahsatunya adalah dengan menggosok gigi.

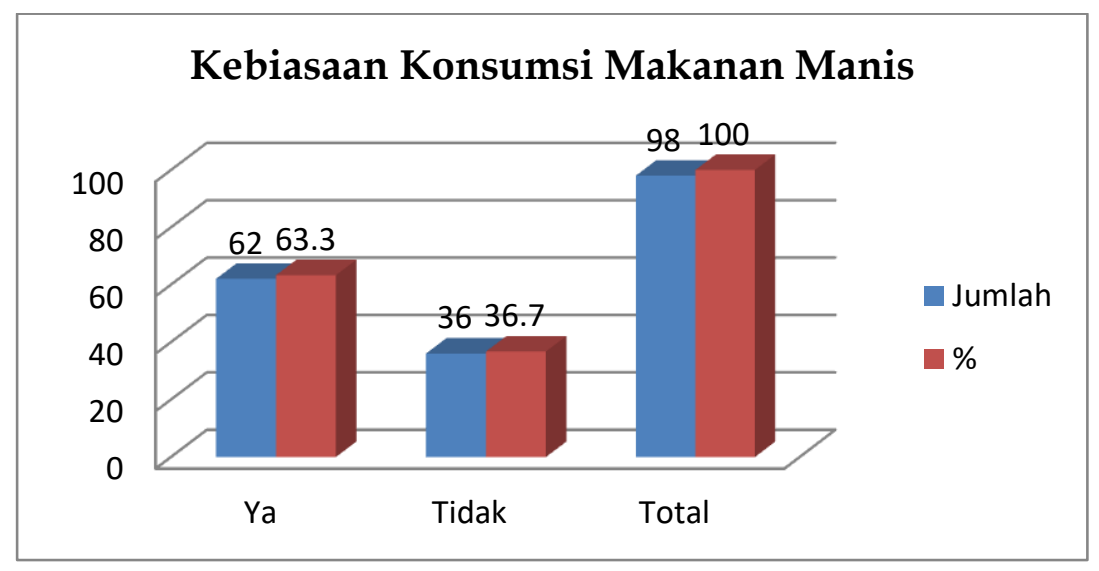

Grafik 3. Kebiasaan konsumsi Makanan Manis 
Berdasarkan grafik 3 dapat dilihat bahwa dari 98 responden sebanyak 62 (63,3\%) anak suka mengkonsumsi makanan manis. Adanya kebiasaan suka minum dan makan makanan yang manis dan lengket dapat menyebabkan terjadinya karies gigi (Lely, 2017). Penelitian ini sejalan dengan penelitian yang dilakukan Ernawati, Arwani, \& Samiasih, (2011) bahwa sebagian besar responden sering mengkonsumsi makanan manis yaitu sebesar $(66,0 \%)$. Makanan manis dan lengket mengandung karbohidrat yang merupakan sumber energi utama bagi bakteri mulut dan secara langsung terlibat dalam penurunan $\mathrm{pH}$. Jenis karbohidrat yang paling cocok bagi produksi asam oleh bakteri di dalam plak adalah gulagula sederhana, seperti sukrosa, glukosa, fruktosa, maltosa, dan lain-lain. Gula-gula ini mempunyai molekul yang kecil sehingga mudah berdifusi ke dalam plak dan dengan cepat akan dipecah oleh bakteri menjadi asam, sehingga dapat menyebabkan demineralisasi pada jaringan keras gigi (Dawani et al., 2012) . Tindakan pencegahan dan perawatan karies perlu dilakukan untuk mencegah terinfeksinya gigi anak dari bakteri kariostat pada saat anak mengonsumsi makanan kariogenik yang tinggi kandungan sukrosanya/makanan manis (Mariati, 2015).

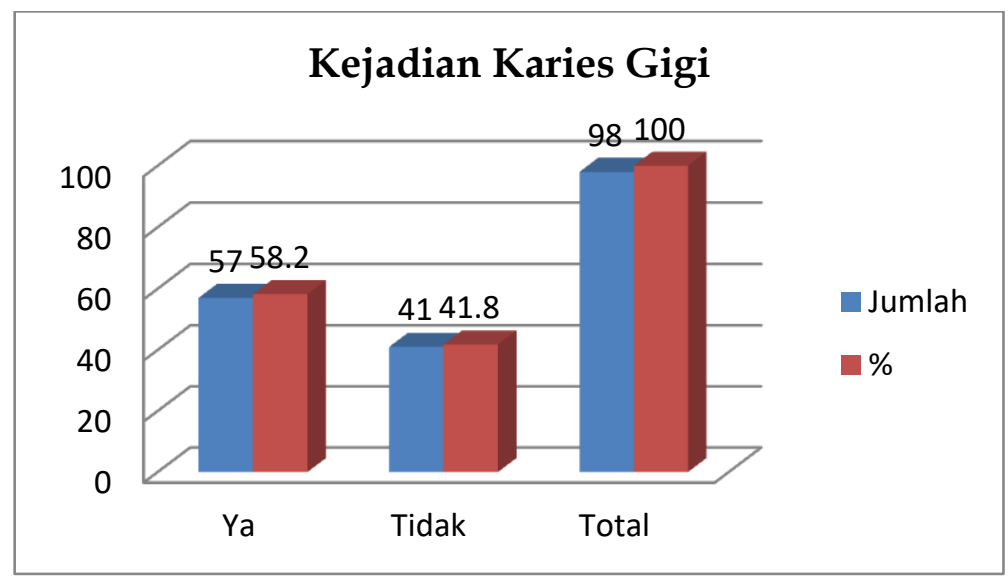

Grafik 4. Kejadian karies gigi anak

Berdasarkan grafik 4 dapat dilihat bahwa dari 98 responden sebanyak 57 anak $(58,2 \%)$ mengalami karies gigi. Hal ini memberikan gambaran bahwa sebagian besar anak mengalami karies gigi. Hasil penelitian ini sejalan dengan yang dilakukan oleh Ernawati et al., (2011), dan Handayani, R., Safitri (2016) yang menyatakan bahwa sebagian besar anak mengalami karies. Kejadian karies gigi tersebut dapat disebabkan oleh pola makan anak yang menyukai makanan manis dan kebiasaan anak yang jarang menggosok gigi. Karies gigi pada anak yang dapat menimbulkan gangguan dalam proses pencernaan dan kesulitan makan yang dapat menyebabkan gangguan pertumbuhan dan perkembangan (Kartikasari \& Nuryanto, 2014).

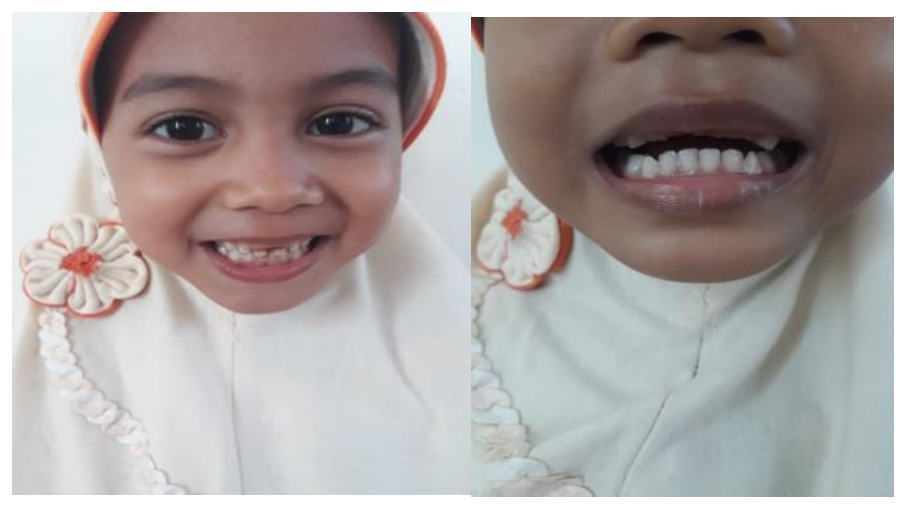

Gambar 1. Kejadian karies 
DOI: $10.31004 /$ obsesi.v5i1.668

Analisa bivariat digunakan untuk menggambarkan hubungan pengetahuan ibu tentang kesehatan gigi dan mulut, kebiasaan menggosok gigi dan konsumsi makanan manis dengan kejadian karies gigi di TK Melati Dharma Wanita Kabupaten Kampar Riau.

Tabel 1 Hubungan pengetahuan ibu dengan kejadian karies gigi

\begin{tabular}{lcccccccc}
\hline \multirow{2}{*}{ Pengetahuan Ibu } & \multicolumn{4}{c}{ Karies Gigi } & \multicolumn{2}{c}{ Total } & \multirow{2}{*}{ P value } \\
\cline { 2 - 6 } & \multicolumn{3}{c}{ Ya } & \multicolumn{2}{c}{ Tidak } & & & P \\
& $\mathrm{n}$ & $\%$ & $\mathrm{n}$ & $\%$ & $\mathrm{n}$ & $\%$ & \\
\hline Kurang & 38 & 73,1 & 14 & 26,9 & 52 & 53,1 & 0,003 \\
Baik & 19 & 41,3 & 27 & 58,7 & 46 & 46,9 & \\
\hline \multicolumn{1}{c}{ Jumlah } & $\mathbf{5 7}$ & $\mathbf{5 8 , 2}$ & $\mathbf{4 1}$ & $\mathbf{4 1 , 8}$ & $\mathbf{9 8}$ & $\mathbf{1 0 0}$ & \\
\hline
\end{tabular}

Berdasarkan tabel 1 diketahui bahwa dari 52 ibu yang berpengetahuan kurang tentang kesehatan gigi dan mulut, terdapat 14 ibu (26,9\%) yang anaknya tidak mengalami karies gigi. Sedangkan dari 46 ibu yang berpengetahuan baik tentang kesehatan gigi dan mulut, terdapat $19 \mathrm{ibu}(41,3 \%)$ yang anaknya mengalami karies gigi. Berdasarkan uji statistik diperoleh nilai $\mathrm{p}=0,003(\mathrm{p}<0,05)$, sehingga ada hubungan yang signifikan antara pengetahuan ibu tentang kesehatan gigi dan mulut dengan kejadian karies gigi. Ibu yang memiliki pengetahuan kurang tentang kesehatan gigi dan mulut cenderung anaknya mengalami karies gigi, sedangkan ibu dengan pengetahuan baik, anaknya cenderung tidak mengalami karies gigi

Pengetahuan ibu tentang kesehatan gigi sangat penting karena merupakan faktor yang penting dalam memberikan pengaruh pada kesehatan dan penyakit gigi anak (Jayanti, 2012). Hasil penelitian ini sesuai dengan penelitian yang dilakukan oleh El Fithriyah \& Herryawan (2018) terdapat hubungan yang signifikan antara tingkat pengetahuan ibu mengenai kebersihan gigi dan mulut dengan kejadian karies pada anak usia pra sekolah di kota Cimahi.

Orang tua harus memiliki pengetahuan dan kesadaran yang baik dalam menjaga kesehatan gigi anak. Anak-anak yang orang tuanya memiliki pengetahuan rendah tentang kebersihan mulut yang benar beresiko mengalami karies gigi lebih tinggi dibandingkan anak-anak yang orang tuanya memiliki pengetahuan lebih baik (Mahat \& Bowen, 2017). Rendahnya pengetahuan ibu tentang kesehatan gigi dan mulut dipengaruhi oleh tingkat pendidikan karena tingkat pendidikan seseorang mempengaruhi kemampuan orang tersebut dalam menerima dan merespon terhadap informasi. Semakin baik tingkat pendidikan seseorang, maka kemampuan untuk memahami dan merespon suatu informasi menjadi pengetahuan semakin baik. Responden yang pengetahuan baik tentang kesehatan gigi dan mulut tetapi anaknya menderita karies gigi disebabkan karena orang tua responden yang sibuk bekerja sehingga tidak bisa memantau makanan yang dikonsumsi anak di sekolah dan dirumah, serta kebiasaan anak yang suka mengkonsumsi makanan manis.

Untuk melihat hubungan kebiasaan menggosok gigi dengan kejadian karies gigi di TK Melati Dharma Wanita dapat dilihat pada tabel 2 berikut:

Tabel 2 Hubungan Kebiasaan Menggosok Gigi dengan kejadian karies gigi

\begin{tabular}{|c|c|c|c|c|c|c|c|}
\hline \multirow{3}{*}{$\begin{array}{c}\text { Kebiasaan } \\
\text { Menggosok Gigi }\end{array}$} & \multicolumn{4}{|c|}{ Karies Gigi } & \multirow{2}{*}{\multicolumn{2}{|c|}{ Total }} & \multirow{3}{*}{ P valu } \\
\hline & \multicolumn{2}{|c|}{$\mathrm{Ya}$} & \multicolumn{2}{|c|}{ Tidak } & & & \\
\hline & $\mathrm{N}$ & $\%$ & $\mathrm{n}$ & $\%$ & $\mathrm{n}$ & $\%$ & \\
\hline Kurang Baik & 43 & 72,9 & 16 & 27,1 & 59 & 60,2 & 0,001 \\
\hline Baik & 14 & 35,9 & 25 & 64,1 & 39 & 39,8 & \\
\hline Jumlah & 57 & 58,2 & 41 & 41,8 & 98 & 100 & \\
\hline
\end{tabular}


DOI: 10.31004/obsesi.v5i1.668

Berdasarkan tabel 2 dapat diketahui bahwa dari 59 siswa yang memiliki kebiasaan menggosok gigi yang kurang baik, terdapat 16 siswa $(27,1 \%)$ yang tidak mengalami karies gigi. Sedangkan dari 39 siswa yang memiliki kebiasaan menggosok gigi baik, terdapat 14 siswa $(35,9 \%)$ yang mengalami karies gigi. Berdasarkan uji statistik diperoleh nilai $p=0,001$ $(\mathrm{p}<0,05)$, sehingga ada hubungan kebiasaan menggosok gigi dengan kejadian karies gigi. Anak yang memiliki kebiasaan menggosok gigi kurang baik, cenderung mengalami karies gigi, sedangkan anak yang memiliki kebiasaan baik menggosok gigi,sebagian besar tidak mengalami karies gigi.

Penyebab utama gigi berlubang (karies) adalah pola hidup yang tidak sehat, terutama berkaitan dengan menyikat gigi sesudah makan. Sisa-sisa makanan yang tertinggal di sela-sela gigi jika tidak segera dibersihkan, akan diuraikan oleh bakteri. Penelitian sejalan dengan penelitian Ernawati et al., (2011) menunjukkan bahwa ada hubungan antara perilaku menggosok gigi dengan kejadian karies gigi pada anak TK Pertiwi 37 Gunungpati Semarang $(p=0,001)$. Hal ini menunjukkan perilaku menggosok gigi buruk akan mudah terkena karies gigi yaitu berupa terbentuknya plak, selanjutnya menyebabkan PH menjadi asam dan terjadi demineralisasi yang pada akhirnya gigi anak menjadi berlubang. Dengan menggosok gigi akan terawat gigi sehingga peluang untuk menderita karies gigi kecil. Responden yang kebiasaan menggosok gigi baik tetapi menderita karies gigi disebabkan karena kurang tepatnya waktu menggosok gigi seperti anak sering menggosok gigi di waktu sore hari bukan setelah makan dan sebelum tidur. Keberhasilan perawatan gigi anak diperlukan peran serta orang tua. Peran serta orang tua dibutuhkan di dalam membimbing, mengingatkan dan memberikan fasilitas agar anak dapat memelihara kebersihan gigi dan mulutnya

Untuk melihat hubungan konsumsi makanan manis dengan kejadian Karies Gigi di TK Melati Dharma Wanita Tahun 2019 dapat dilihat pada tabel berikut:

Tabel 3 Hubungan konsumsi makanan manis dengan kejadian karies gigi Konsumsi Makanan Manis

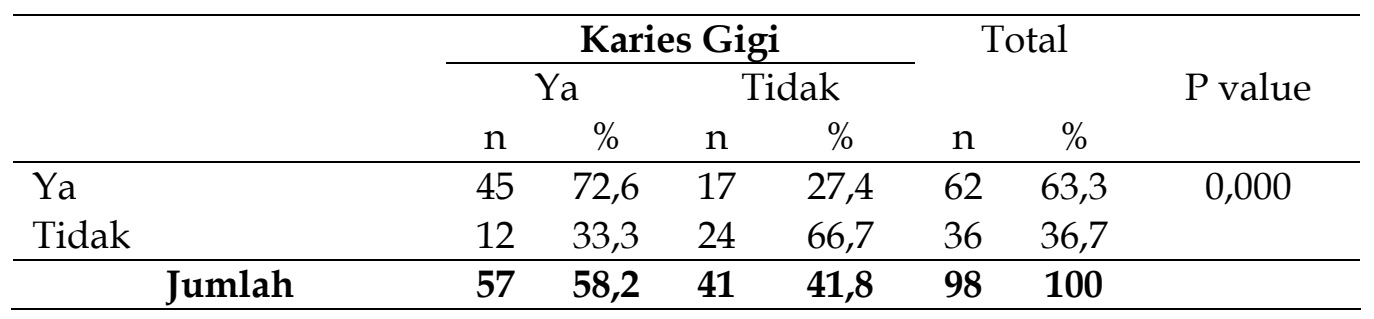

Berdasarkan hasil uji chi square dapat diketahui bahwa dari 62 siswa yang mengkonsumsi makanan manis terdpat 17 siswa $(27,4 \%)$ yang tidak mengalami karies gigi. Sedangkan dari 36 siswa yang tidak mengkonsumsi makanan manis, terdapat 12 siswa $(33,3 \%)$ yang mengalami karies gigi. Berdasarkan uji statistik diperoleh nilai $\mathrm{p}=0,000(\mathrm{p}<$ 0,05 ). Ini berarti ada hubungan yang signifikan antara konsumsi makanan manis dengan kejadian karies gigi. Anak yang memiliki kebiasaan konsumsi makanan manis, cenderung mengalami karies gigi, sedangkan anak yang tidak mengkonsumsi makanan manis, sebagian besar tidak mengalami karies gigi. Pada anak prasekolah, karies gigi banyak disebabkan karena adanya kebiasaan yang kurang baik seperti kebiasaan mengkonsumsi makanan yang manis atau yang mengandung gula murni seperti permen, cokelat, dan donat (Ernawati et al., 2011).

Kebiasaan anak yang suka makanan manis, lengket dan minum susu, pemberian makan dan minum sebelum tidur malam, pemberian susu (ASI atau formula) di malam hari, penambahan gula pada minuman anak, kebiasaan orang tua memberikan makanan berserat, dan pemberian makanan selingan diantara jam makan (Widayati, 2014). 
Makanan yang mengandung karbohidrat misalnya sukrosa dan gula atau makanan yang manis yang mudah menempel pada gigi yang dapat diragikan oleh bakteri tertentu dan membentuk asam sehingga dapat menjadi plak dan merusak struktur gigi jika dibiarkan begitu saja dalam kurun waktu yang lama akan menyebabkan terjadinya karies (Rahayu \& Asmara, 2018). Sisa makanan manis yang menempel pada permukaan gigi maupun pada sela-sela gigi akan diubah menjadi asam oleh bakteri, jika hal tersebut dibiarkan maka akan dapat merusak lapisan gigi dan berakibat karies gigi.

Orang tua dapat mengurangi risiko terjadinya karies gigi dengan melakukan cara pencegahan karies dengan berkumur dengan air bersih setelah minum susu maupun makan makanan yang manis dan menggosok gigi untuk menjaga kebersihan gigi dan mulut. Orang tua juga harus membiasakan anaknya memeriksakan gigi mereka ke dokter gigi 2 kali dalam 1 tahun (Winda et al., 2015).

\section{SIMPULAN}

Berdasarkan uraian di atas, dapat disimpulkan bahwa terdapat hubungan yang signifikan antara pengetahuan ibu tentang kesehatan gigi dan mulut dengan kejadian karies gigi anak usia dini. Ibu yang memiliki pengetahuan kurang tentang kesehatan gigi dan mulut cenderung anaknya mengalami karies gigi. Terdapat hubungan signifikan antara kebiasaan menggosok gigi dengan kejadian karies gigi. Anak yang memiliki kebiasaan menggosok gigi kurang baik, cenderung mengalami karies gigi. Ada hubungan signifikan antara konsumsi makanan manis dengan kejadian karies gigi anak TK Melati Dharma Wanita Kampar Riau. Anak yang memiliki kebiasaan konsumsi makanan manis, cenderung mengalami karies gigi.

\section{UCAPAN TERIMA KASIH}

Peneliti mengucapkan terimakasih kepada pihak TK Melati Dharma Wanita Kampar Riau dan Universitas Pahlawan Tuanku Tambusai yang telah banyak membantu dan memberikan semangat dan dukungan kepada peneliti sampai penelitian ini selesai. Ucapan terima kasih juga disampaikan kepada tim editor Jurnal Obsesi yang telah memberikan saran, kritik, dan rekomendasi untuk perbaikan artikel ini.

\section{DAFTAR PUSTAKA}

Alshehri, A., \& Nasim, V. S. (2015). Infant oral health care knowledge and awareness among parents in Abha city of Aseer Region, Saudi Arabia. Saudi Journal for Dental Research, 6(2), 98-101. https://doi.org/10.1016/j.sjdr.2015.01.001

Dawani, N., Nisar, N., Khan, N., Syed, S., \& Tanweer, N. (2012). Prevalence and factors related to dental caries among pre-school children of Saddar town, Karachi, Pakistan: A cross-sectional study. BMC Oral Health, 12(1), 1. https://doi.org/10.1186/14726831-12-59

El Fithriyah, R., \& Herryawan. (2018). Hubungan Tingkat Pengetahuan Ibu Tentang Pencegahan Karies Dan Hubungannya Dengan Kejadian Early Childhood Caries Pada Anak Usia Pra Sekolah Di Kota Cimahi. Medika Kartika Jurnal Kedokteran Dan Kesehatan, 1(Volume 1 No 2), 106-144. https:/ / doi.org/10.35990/mk.v1n2.p106-144

Ernawati, Arwani, \& Samiasih. (2011). Hubungan Antara Perilaku Mengkonsumsi Makan Makanan Manis Dan Perilaku Menggosok Gigi Dengan Kejadian Karies Gigi Pada Anak Tk Pertiwi 37 Gunung Pati. Fikkes Jurnal Keperawatan, 4(183-193), 1-12.

Fatimatuzzahro, N., Prasetya, R. C., \& Amilia, W. (2016). Gambaran Perilaku Kesehatan Gigi Anak Sekolah Dasar di Desa Bangalsari Kabupaten Bantaeng. Jurnal IKESMA, 12(2), 85.

Handayani, R., Safitri, M. (2016). Hubungan Perawatan Gigi Dengan Kejadian Karies Gigi Di wilayah Kerja Di Puskesmas Air Tawar Padang. Jurnal E-Gigi, 59-60(2), 193-200.

Jayanti, C. D. (2012). Hubungan Tingkat Pengetahuan Ibu Tentang Karies Gigi Dengan 
DOI: 10.31004/obsesi.v5i1.668

Kejadian Karies Gigi Pada Anak Tk Aisyiyah Kateguhanan Sawit Boyolali. Naskah Publikasi, 1-12.

Kartikasari, H. Y., \& Nuryanto, N. (2014). Hubungan Kejadian Karies Gigi dengan Konsumsi Makanan Kariogenik dan Status Gizi pada Anak Sekolah Dasar (Studi pada Anak Kelas III dan IV SDN Kadipaten I dan II Bojonegoro). Journal of Nutrition College, 3(3), 414-421. https://doi.org/10.14710/jnc.v3i3.6605

Lely, M. A. (2017). Pengaruh (pH) Saliva terhadap Terjadinya Karies Gigi pada Anak Usia Prasekolah. Buletin Penelitian Kesehatan, 45(4), 241-248. https://doi.org/10.22435/bpk.v45i4.6247.241-248

Lintang, J. C., Palandeng, H., \& Leman, M. A. (2015). Hubungan Tingkat Pengetahuan Pemeliharaan Kesehatan Gigi Dan Tingkat Keparahan Karies Gigi Siswa Sdn Tumaluntung Minahasa Utara. E-GIGI, 3(2). https://doi.org/10.35790/eg.3.2.2015.10370

Mahat, G., \& Bowen, F. (2017). Parental knowledge about urban preschool children's oral health risk. Pediatric Nursing, 43(1), 30-34.

Mariati, N. W. (2015). Pencegahan Dan Perawatan Karies Rampan. Jurnal Biomedik (Jbm), 7(1). https://doi.org/10.35790/jbm.7.1.2015.7288

Penelitian dan Pengembangan Kesehatan Kementerian Kesehatan RI. (2018). Laporan Riskesdas 2018. Journal of Chemical Information and Modeling, 53(9), 181-222. https:// doi.org/10.1017/CBO9781107415324.004

Putri Abadi, N. Y. W., \& Suparno, S. (2019). Perspektif Orang Tua pada Kesehatan Gigi Anak Usia Dini. Jurnal Obsesi: Jurnal Pendidikan Anak Usia Dini, 3(1), 161. https://doi.org/10.31004/obsesi.v3i1.161

Rahayu, S., \& Asmara, L. I. (2018). Hubungan Mengkonsumsi Makanan Kariogenik Dan Pola Menyikat Gigi Dengan Kejadian Karies Gigi Pada Anak Usia Sekolah. KOSALA: Jurnal Ilmu Kesehatan, 6(2). https:// doi.org/10.37831/jik.v6i2.147

Rompis, C., Pangemanan, D., \& Gunawan, P. (2016). Hubungan tingkat pengetahuan ibu tentang kesehatan gigi anak dengan tingkat keparahan karies anak TK di Kota Tahuna. E-GIGI, 4(1). https:/ / doi.org/10.35790/eg.4.1.2016.11483

Sari. (2014). Hubungan Kebiasaan Menggosok Gigi Dengan Timbulnya Karies Gigi Pada Anak Usia Sekolah Kelas 4-6 Di Sdn Ciputat 6 Tangerang Selatan Provinsi Banten Tahun 2013. Fakultas Kedokteran Dan Ilmu Kesehatan Universitas Islam Negeri Syarif Hidayatullah, 64 .

Sukarsih. (2018). Hubungan Pengetahuan Ibu tentang Pemeliharaan Kesehatan Gigi dengan Status Karies pada Anak TK Al-Hikmah Kota Jambi tahun 2018. Jurnal Bahan Kesehatan Masyarakat, Vol 2 No 2(2), 131-134.

Susi, S., Bachtiar, H., \& Azmi, U. (2012). Hubungan Status Sosial Ekonomi Orang Tua Dengan Karies Pada Gigi Sulung Anak Umur 4 Dan 5 Tahun. Majalah Kedokteran Andalas, 36(1), 96. https:// doi.org/10.22338/mka.v36.i1.p96-105.2012

Utami, S. (2018). Faktor-faktor yang Berhubungan dengan Status Karies Gigi Anak Usia Prasekolah Kabupaten Sleman Tahun 2015. Mutiara Medika: Jurnal Kedokteran Dan Kesehatan, 18(2), 67-70. https://doi.org/10.18196/mm.180218

Widayati, N. (2014). Faktor Yang Berhubungan Dengan Karies Gigi Pada Anak Usia 4-6 Tahun (Studi Di Tk Ra Bustanussholihin Desa Balun Kecamatan Turi. Jurnal Berkala Epidemiologi, 2, 197.

Winda, S. U., Gunawan, P., \& Wicaksono, D. A. (2015). Gambaran Karies Rampan Pada Siswa Pendidikan Anak Usia Dini Di Desa Pineleng Ii Indah. E-GIGI, 3(1). https:// doi.org/10.35790/eg.3.1.2015.6630

Worotitjan, I., Mintjelungan, C. N., \& Gunawan, P. (2013). Pengalaman Karies Gigi Serta Pola Makan Dan Minum Pada Anak Sekolah Dasar Di Desa Kiawa Kecamatan Kawangkoan Utara. E-GIGI, 1(1), 59-68. https:/ / doi.org/10.35790/eg.1.1.2013.1931 